\title{
ANALISIS INFORMASI ANATOMI DAN KUALITAS CITRA PADA SEKUENS T1 SE FAT SATURATION IRISAN SAGITAL OBLIQUE DENGAN VARIASI PHASE OVERSAMPLING PADA PEMERIKSAAN MRI ORBITA
}

\author{
${ }^{1}$ Rachman Kusumadi, ${ }^{2}$ Emi Murniati, ${ }^{3}$ Siti Daryati ${ }^{3)}$ \\ 1),2,3) Poltekkes Kemenkes Semarang \\ e-mail : rachman.extentwo@gmail.com
}

\begin{abstract}
Background: Aliasing artifacts often occur on MRI examinations Orbita sequence T1 SE Fat Saturation sagittal oblique slices. One way to eliminate aliasing artifacts is by setting Phase Oversampling (PO). The purpose of this study was to determine differences in anatomic information and image quality in the T1 SE sequence of oblique sagittal fat saturation slices with PO variations of orbital MRI examinations and to determine the value of PO variations that can produce optimal anatomic information and image quality in the sequences of T1 SE Fat Saturation slices sagittal oblique on Orbita MRI examination.

Method: This type of research is quantitative research with an experimental approach. The research subject is Orbita MRI imagery. The research sample consisted of Orbita MRI images obtained from 10 volunteers. Data obtained from SNR and CNR measurements to obtain image quality data, then the image results were assessed by respondents using questionnaires to obtain anatomic information data. The data obtained were analyzed using different tests in the SPSS application.

Results: The results showed that there were significant differences in the anatomy of the lens with aliasing artifact variations in PO 13\%, while PO 52\% and 91\% had no aliasing artifacts. Optic nerve anatomy has a clear and welldefined image at PO $91 \%$ compared to PO $13 \%$ and 52\%. Friedman test results on anatomic information on the anatomy of the Lens, superior Muscle rectus, and Optic nerve are significant with p-value $<0.05$, meaning there are differences in anatomic information with variations in PO. Friedman anatomy test results of Retro orbit, Muscle rectus inferior, and Vitreous are significant with p-value> 0.05 , meaning there is no difference in anatomic information with variations in PO. Furthermore, the results of the study showed that there were differences in image quality (SNR and CNR) against PO variations with significance values $(\mathrm{p}<0.05)$.
\end{abstract}

Conclusion : Based on the calculation of the mean rank Friedman test shows that the more the PO value increases, the quality (SNR and CNR values) increases. The PO 91\% setting produces a more optimal image.

\section{Keywords: Phase Oversampling, Anatomical Information, Image Quality, MRI Orbita}

\section{Pendahuluan}

Pemeriksaan MRI menghasilkan gambaran potongan tubuh manusia dengan menggunakan medan magnet tanpa menggunakan sinar-X. Pemeriksaan dengan menggunakan MRI mampu menghasilkan citra yang lebih baik dan mempunyai beberapa kelebihan diantaranya dapat memberikan gambaran dengan spasial resolusi yang baik, kontras antar jaringan yang baik, tanpa radiasi pengion dan dapat menghasilkan gambaran dengan berbagai potongan (multi planar) yaitu potongan axial, coronal serta sagital tanpa dilakukan rekonstruksi gambar terlebih dahulu (Rasad, 2011).

MRI menciptakan gambar yang dapat menunjukkan perbedaan sangat jelas dan lebih sensitif untuk menilai anatomi jaringan lunak dalam tubuh seperti pemeriksaan MRI abdomen, mata, kepala, vertebra, dan lain sebagainya. Pemeriksaan untuk Orbita dikategorikan advance karena kesulitannya dalam mendapatkan gambaran yang tepat untuk dapat menegakan diagnosa. Dikarenakan organ orbita yang banyak mengandung jaringan-jaringan lunak (Nayak, 2013).

Beberapa pemeriksaan MRI Orbita sering terjadi artefak aliasing karena terlalu kecilnya FOV yang digunakan sehingga organ yang di luar FOV bertumpuk dalam satu gambar. Pemeriksaan tersebut seperti MRI genu, orbita, humerus, brain, spine dan lain-lain. Artefak ini akan mengganggu dalam menegakkan diagnosa. Untuk mengilangkan artefak aliasing biasanya menggunaan phase oversampling. 
Phase oversampling, mempunyai nama lain "No Phase Wrap" atau "Foldover Suppresion". Teknik ini FOV di tingkatkan pada Phase encode direction dan juga meningkatkan jumlah tahapan phase encode sehingga ukuran pixel tetap sama. Setiap penambahan phase encode akan meningkatkan SNR. Peningkatan jumlah langkah phase encoding, akan menghasilkan scan time yang lebih lama (Joachim, 2009).

Berdasarkan studi pendahuluan yang telah peneliti lakukan, pemeriksaan MRI Orbita pada sekuen T1 SE Fat Saturation sagital oblique dextra atau sinistra, pada citra orbita yang dihasilkan seringkali terdapat artefak aliasing dan kendala lain objek orbita yang sangat kecil, memerlukan pembesaran beberapa kali yang menyebabkan kualitas citra kurang optimal. Munculnya artefak tersebut diduga disebabkan oleh pengaturan FOV yang terlalu kecil. Pemeriksaan MRI Orbita menggunakan head coil yang mencakup seluruh kepala tetapi FOV yang diatur hanya sebesar objek yang diinginkan yaitu orbita kanan dan kiri oleh sebab itu peneliti ingin mengubah variasi phase oversampling dari pengaturan awal 13\% menjadi 52\% dan 91\% dan hasil citra setelah perubahan parameter phase oversampling menunjukan pengurangan artefak aliasing.

Berdasarkan hal tersebut, maka penulis ingin mengetahui hasil informasi anatomi dan kualitas citra dengan variasi phase oversampling pada pemeriksaan MRI Orbita. Dan ingin mengetahui phase oversampling berapa yang dapat menghasilkan citra yang optimal. Sehingga penulis ingin menguraikan bahasan tersebut dalam penelitian ini dengan judul "Analisis Informasi Anatomi dan Kualitas Citra pada Sekuen T1 SE Fat Saturation Irisan Sagital Oblique Dengan Variasi Phase Oversampling pada Pemeriksaan MRI Orbita".

\section{Metode}

Penelitian ini adalah penelitian kuantitatif dengan pendekatan eksperimen. Sampel penelitian sebanyak 10 sampel dilakukan pemeriksaan MRI Orbita. Setiap volunteer dilakukan scanning MRI Orbita dengan 3 variasi phase oversampling $(13 \%, 52 \%$, dan $91 \%)$, dengan parameter lain yang diatur tetap. Dari hasil irisan yang dihasilkan, dipilih satu citra yang dapat menampilkan daerah Vitreous, Lensa, Retro Orbita, Muscle Rectus Superior, Muscle Rectus Inferior, dan Optic nerve. Area tersebut pada irisan ke 4. Diperoleh 30 citra pada setiap pemeriksaan dengan variasi phase oversampling pada 10 volunteer.

\section{Pengukuran SNR}

Pengukuran SNR dilakukan dengan cara membuat ROI area $1 \mathrm{~mm}^{2}$ pada 6 area citra orbita pada potongan ke 4. Area area tersebut adalah Vitreous, Lensa, Retro Orbita, Muscle Rectus Superior, Muscle Rectus Inferior, dan Optic Nerve. Lalu melakukan ROI pada 4 area background yang berbeda di luar orbita, dengan menghindari daerah artefak bila ada. Dalam display akan tertera nilai mean dan standar deviasi pada masing - masing daerah terukur. Nilai yang sudah didapatkan kemudian dihitung untuk mendapatkan nilai SNR setiap daerah ROI dengan cara membagi sinyal rata-rata daerah terukur dengan rata-rata standar deviasi pada 4 area background. Rumus pengukuran SNR sebagai berikut:

$$
S N R=\frac{\text { Sinyal Rata-rata anatomi }}{\text { Standar Deviasi Background }}
$$

\section{Pengukuran CNR}

Nilai CNR merupakan selisih dari SNR 2 area objek yang berbeda yang saling berdekatan. Setelah diperoleh nilai SNR pada masing masing objek, maka dilakukan pengukuran CNR. Rumus pengukuran CNR sebagai berikut :

Keterangan :

$$
\mathrm{CNR}_{\mathrm{ab}}=\mathrm{S}_{\mathrm{a}}-\mathrm{S}_{\mathrm{b}}
$$

$\mathrm{CNR}_{\mathrm{ab}}$ : Contrast to Noise Ratio antara jaringan a dan jaringan $b$

$\mathrm{Sa} \quad$ : Intensitas jaringan a

$\mathrm{Sb} \quad$ : Intensitas jaringan $\mathrm{b}$

\section{Evaluasi Informasi Anatomi}

Film tanpa identitas dan keterangan sekuen diberikan kepada dokter spesialis radiologi. Penilaian dilakukan terhadap informasi citra meliputi kejelasan organ daerah orbita.

Pemberian nilai dilakukan dengan cara memberikan skor pada kolom kuisioner sesuai dengan nilai dari kejelasan masing-masing jaringan lunak pada daerah orbita, yaitu. Skor 3 berarti "sangat jelas" diberikan apabila organ yang dinilai tampak jelas, dan berbatas tegas. Skor 2 berarti "jelas" diberikan apabila organ yang dinilai tampak jelas namun tidak berbatas tegas. Dan skor 1 berarti "tidak jelas" diberikan apabila organ yang dinilai tidak terlalu jelas dan tidak berbatas tegas.

Hasil pengukuran SNR, CNR, dan penilaian informasi citra dicatat dan dianalisis menggunakan SPSS 23 untuk mengetahui perbedaan informasi anatomi dan kualitas citra (nilai SNR dan CNR) terhadap phase oversampling.

\section{Pengolahan dan Analisis Data}

Data hasil kuisoner yang diperoleh dari hasil responden 2 dokter spesialis Radiologi terhadap 30 citra pada sekuen T1 SE Fat Saturation irisan sagital oblique pada pemeriksaan MRI Orbit. Hasil penilaian kedua dokter spesialis radiologi dilakukan uji Kappa untuk mengetahui tingkat obyektifitas dari penilaian ke-2 responden terhadap variasi phase oversampling tersebut. Data dari hasil penilaian dokter diolah dan di analisis dengan SPSS menggunakan uji friedman untuk mengetahui apakah ada perbedaan yang bermakna dari variasi Phase Oversampling dan uji mean rank untuk mengetahui perubahan nilai variasi Phase Oversampling yang dapat menghasilkan citra optimal.

Setelah dilakukan pengukuran nilai SNR dan CNR, Kemudian data kualitas citra (nilai SNR dan nilai CNR) yang berupa data rasio dengan jumlah data 30 maka data tidak berdistribusi normal sehingga di lanjutkan uji friedman. Uji tersebut untuk mengetahui pada perbedaan yang bermakna dari variasi Phase Oversampling. Kemudian dilakukan analisis mean rank untuk mengetahui nilai variasi Phase Oversampling yang paling optimal. 


\section{Hasil dan Pembahasan}

\section{Karakteristik Sampel dan Responden}

Penelitian yang dilakukan di Instalasi Radiologi RS Telogorejo semarang untuk mengetahui pengaruh phase oversampling terhadap informasi anatomi dan kualitas citra pada pemeriksaan MRI Orbita.

Sampel pada penelitian ini dilakukan pada 10 volunteer berjenis kelamin laki-laki dan perempuan Berdasarkan jenis kelamin pasien, distribusi 10 sampel pada penelitian ini terdiri dari 4 pasien perempuan (40\%) dan 6 pasien laki-laki $(60 \%)$. Disajikan dalam tabel sebagai berikut:

Tabel 1. Karakteristik Sukarelawan berdasarkan Jenis Kelamin

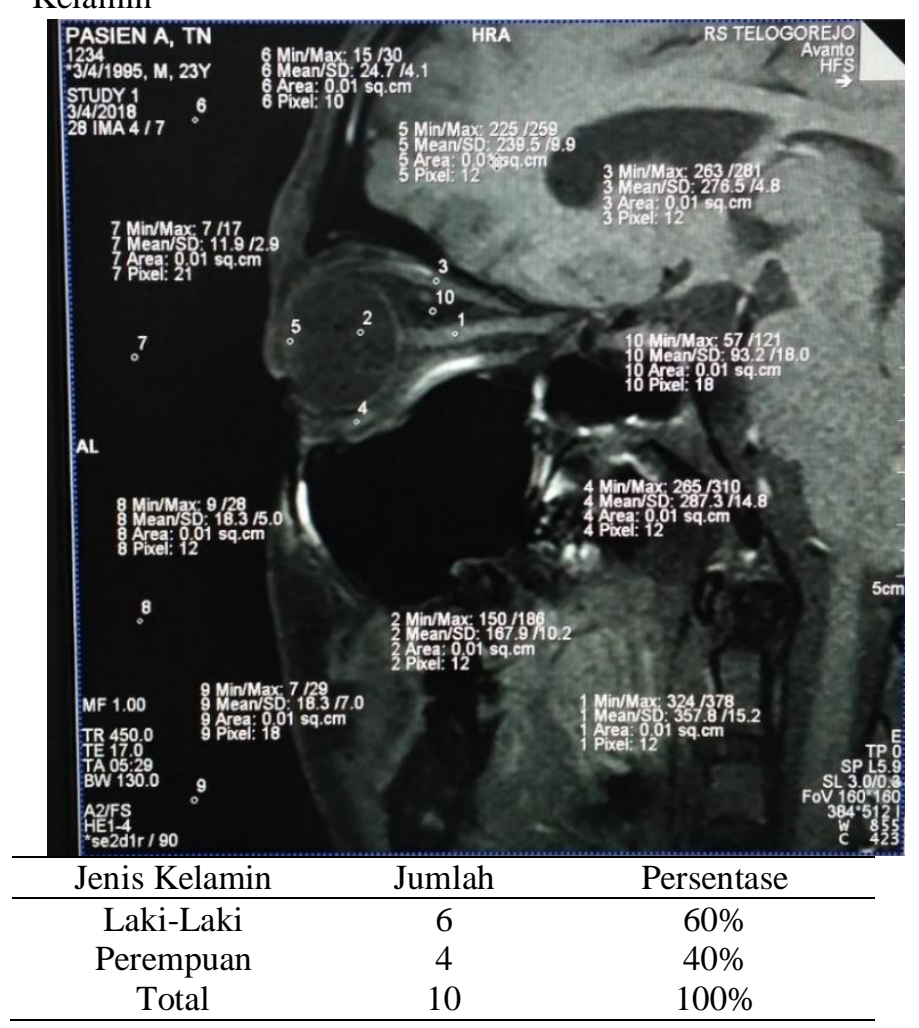

Ke-sepuluh (10) volunteer tersebut dilakukan penelitian dengan variasi phase oversampling 13\%, 52\%, dan $91 \%$. Setiap volunteer dilakukan 3 (tiga) variasi phase oversampling menghasilkan 30 citra yang dapat menampakkan anatomi Vitreous, Lensa, Retro orbita, Muscle rectus superior, Muscle rectus inferior, dan Optic nerve.

Hasil citra MRI Orbita sekuen T1 SE Fat Saturation pada potongan sagital oblique dilakukan penilaian kriteria citra anatomi oleh 2 dokter spesialis radiologi dengan pengalaman membaca citra MRI minimal 5 tahun. Dokter pertama adalah dokter spesialis radiologi yang berpengalaman kerja di bidang radiologi selama 23 tahun dan dokter kedua adalah spesialis radiologi yang sudah berpengalaman dalam menilai hasil citra MRI selama 10 tahun. Sistem penilaian terbagi menjadi 3 yakni nilai 1 untuk citra tidak jelas (jika gambaran anatomi yang dinilai tidak terlalu jelas dan tidak berbatas tegas), nilai 2 untuk citra jelas (jika gambaran anatomi yang dinilai tampak jelas namun tidak berbatas tegas), dan nilai 3 untuk citra sangat jelas (jika gambaran anatomi tampak jelas dan berbatas tegas).

Hasil citra juga di lakukan pengukuran SNR dan CNR pada setiap anatomi seperti Vitreous, Lensa, Retro orbita, Muscle rectus superior, Muscle rectus inferior, dan Optic nerve. Perhitungan SNR adalah dengan membagi sinyal ratarata (mean) area anatomi dengan standar deviasi dari background (McRobbie, 2006).

Gambar 1. Hasil ROI pada Citra MRI Orbita

Pengukuran SNR menggunakan rumus sebagai berikut :

$$
S N R=\frac{\text { Sinyal Rata-rata anatomi }}{\text { standar Deviasi Background }}
$$

Contoh pada pengukuran SNR anatomi vitreous maka hasil ROI menunjukan hasil nilai rata-rata (mean) adalah 167,9 dan hasil rata-rata Standar deviasi background adalah 4,7 maka:

$$
\begin{aligned}
\text { SNR } & =\frac{\text { Sinyal Rata-rata anatomi }}{\text { Standar Deviasi Background }} \\
& =\frac{167,9}{4,7} \\
& =35,7
\end{aligned}
$$

Sedangkan untuk pengukuran CNR dengan cara selisih antara nilai SNR yang saling berdekatan, rumus sebagai berikut:

$$
\mathrm{CNR}_{\mathrm{ab}}=\mathrm{SNR}_{\mathrm{a}}-\mathrm{SNR}_{\mathrm{b}}
$$

Contoh pada salah satu pengukuran CNR antara anatomi Optic nerve dengan Vitreous dihasilkan nilai SNR Optic nerve 76,1 dan nilai SNR Vitreous 35,7 maka :

$$
\begin{aligned}
\mathrm{CNR}_{\mathrm{ab}} & =\mathrm{SNR}_{\mathrm{a}}-\mathrm{SNR}_{\mathrm{b}} \\
& =76,1-35,7 \\
& =40,4 .
\end{aligned}
$$

\section{Pengujian Kappa Terhadap Dua Responden}

Pengujian statistika kappa untuk mengetahui tingkat kesamaan atau kesepakatan persepsi antara dua responden dalam pemberian skor penilaian citra. Hasil pengujian Kappa terhadap dua responden adalah sebagai berikut:

Tabel 2. Hasil pengukuran kesepakatan kappa

\begin{tabular}{ccc}
\hline Variasi Phase oversampling & Kappa value & Approx sig \\
\hline $13 \%$ & 0,917 & 0,000 \\
$52 \%$ & 0,619 & 0,000 \\
$91 \%$ & 0,634 & 0,000 \\
\hline
\end{tabular}

Pengujian kesepakatan kappa dilakukan pada tiap variable independen, hasil pada variasi Phase oversampling $13 \%$ pengukuran kappa-nya adalah 0,917 dengan signifikansi $0,000$ ( $p<0,05)$, pengukuran kappa pada variasi Phase oversampling $52 \%$ pengukuran kappa-nya adalah 0,619 dengan signifikansi 0,000 ( $p<0,05)$, pengukuran kappa pada variasi Phase oversampling $91 \%$ pengukuran kappa-nya adalah 0,634 dengan signifikansi 0,000 ( $p<0,05)$.

Menurut Sopiyudin (2011) apabila reliabilitas kappa antara dua responden lebih dari 0,61 sampai dengan 0.8 berarti kesepakan atau kesesuaian antara kedua responden itu baik. Dengan demikian, responden yang terlibat dalam penelitian 
ini hanya satu responden saja yaitu responden dengan pengalaman kerja 23 tahun.

Uji Statistik pada Informasi Anatomi dan Kualitas Citra

Infromasi anatomi merupakan hasil dari scanning MRI Orbita dengan variasi Phase Oversampling. Penilaian informasi anatomi menggunakan check list yang dinilai oleh dokter Radiologi sebagai obvserver.

Tabel 3. Hasil Akumulasi Penilaian Observer

\begin{tabular}{cccc}
\hline \multirow{2}{*}{ Volunter } & \multicolumn{3}{c}{ Phase Oversampling } \\
\cline { 2 - 4 } & $13 \%$ & $52 \%$ & $91 \%$ \\
\hline 1 & 9 & 11 & 15 \\
\hline 2 & 13 & 12 & 14 \\
\hline 3 & 10 & 14 & 15 \\
\hline 4 & 11 & 13 & 9 \\
\hline 5 & 11 & 15 & 17 \\
\hline 6 & 10 & 12 & 13 \\
\hline 7 & 11 & 10 & 11 \\
\hline 8 & 8 & 12 & 14 \\
\hline 9 & 8 & 15 & 11 \\
\hline 10 & 13 & 12 & 16 \\
\hline
\end{tabular}

Dari tabel 3. dapat dilihat hasil penilaian responden. Data tersebut merupakan hasil akumulasi penilaian responden pada 6 area anatomi.

\section{Hasil Informasi Anatomi pada Setiap Anatomi}

Dari peneltian didapatkan informasi anatomi citra dari salah satu pasien sebagai berikut:

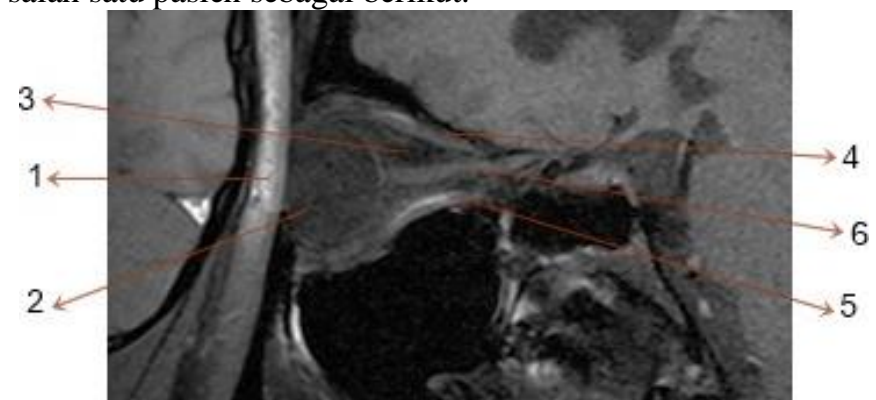

(A)

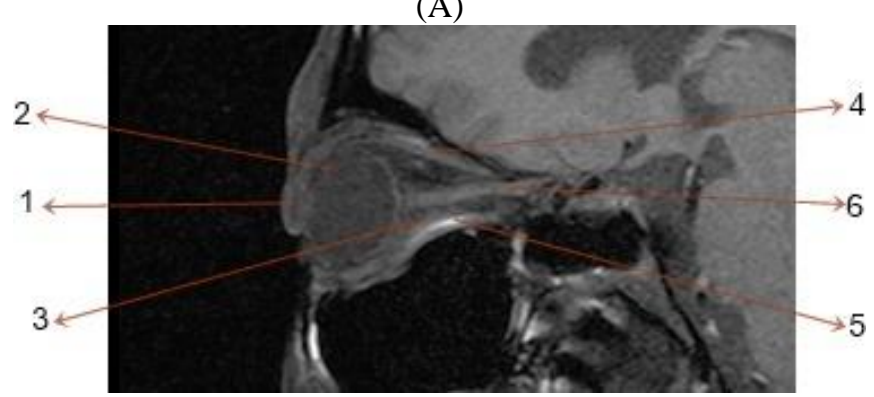

(B)

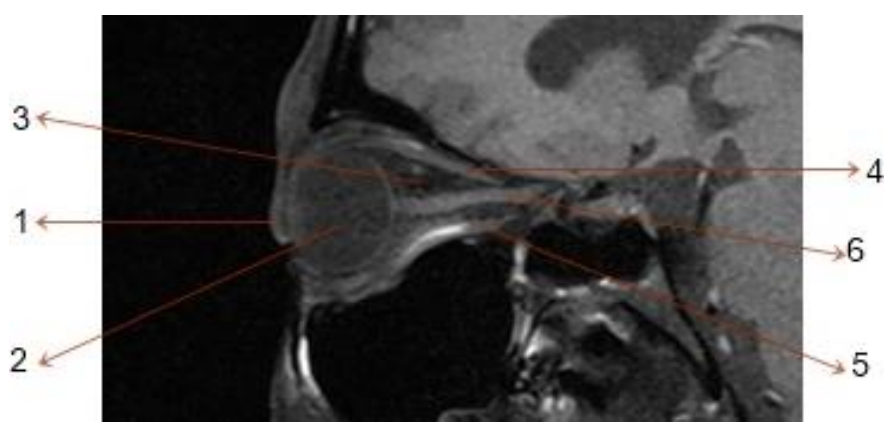

(C)

Gambar 2. (A) Hasil Citra Phase Oversampling 13\%. (B)

Phase Oversampling 52\%. (C) Phase Oversampling 91\%

Keterangan :

1. Lensa

2. Vitreous

3. Retro Orbita

4. Muscle Rectus Superior

5. Muscle Rectus Inferior

6. Optic Nerve

Pengujian menggunakan uji friedman dilakukan untuk mengetahui perbedaan informasi anatomi irisan sagital oblique sekuen T1 SE Fat Saturation dengan variasi phase oversampling dengan kriteria anatomi Vitreous, Lensa, Retro orbita, Muscle rectus superior, Muscle rectus inferior, Optic nerve terhadap 10 pasien sebagai berikut:

Tabel 4. Hasil uji Friedman Informasi Anatomi pada Setiap Anatomi

\begin{tabular}{ccc}
\hline Kriteria anatomi & $\begin{array}{c}\text { Asymp. } \\
\text { Sig. }\end{array}$ & Keterangan \\
\hline Vitreous & 0.347 & $\begin{array}{c}\text { Tidak ada perbedaan } \\
\text { informasi anatomi Vitreous }\end{array}$ \\
\hline Lensa & 0.004 & $\begin{array}{c}\text { Ada perbedaan informasi } \\
\text { anatomi Lensa }\end{array}$ \\
Retro Orbita & 0.452 & $\begin{array}{c}\text { Tidak ada perbedaan } \\
\text { informasi anatomi Retro } \\
\text { Orbita }\end{array}$ \\
\hline $\begin{array}{c}\text { Muscle Rectus } \\
\text { superior }\end{array}$ & 0.026 & $\begin{array}{c}\text { Ada perbedaan informasi } \\
\text { anatomi Muscle Rectus } \\
\text { Superior }\end{array}$ \\
\hline $\begin{array}{c}\text { Muscle Rectus } \\
\text { inverior }\end{array}$ & 0.326 & $\begin{array}{c}\text { Tidak ada perbedaan } \\
\text { informasi anatomi Muscle } \\
\text { Rectus Inferior }\end{array}$ \\
\hline $\begin{array}{c}\text { Optic nerve } \\
\text { Onda perbedaan informasi } \\
\text { anatomi Optic Nerve }\end{array}$ \\
\hline
\end{tabular}

1. Vitreous

Dari hasil uji friedman pada tabel 4 menunjukan bahwa ( $\mathrm{p}<0,05$ ), yakni nilai $p$-value Vitreous 0.342 , berarti tidak ada perbedaan terhadap variasi phase oversampling sedangkan secara penilaiaan responden juga menunjukan bahwa tidak terdapat perbedaan, dan dapat dilihat pada gambar 2 .

2. Lensa

Dari hasil uji friedman pada tabel 4 menunjukan bahwa ( $\mathrm{p}<0,05$ ), yakni nilai $p$-value Lensa 0.004 , berarti ada 
perbedaan terhadap variasi phase oversampling sedangkan secara objektif yaitu penilaiaan responden menunjukan bahwa terdapat perbedan, dan dapat dilihat pada gambar 2 .

\section{Retro Orbita}

Dari hasil uji friedman pada tabel 4 menunjukan bahwa ( $p>0,05$ ), yakni nilai p-value Retro Orbita 0.452 , berarti tidak ada perbedaan terhadap variasi phase oversampling sedangkan secara penilaiaan responden juga menunjukan bahwa tidak terdapat perbedaan dan dapat dilihat pada gambar 2 .

\section{Muscle Rectus Superior}

Dari hasil uji friedman pada tabel 4 menunjukan bahwa ( $\mathrm{p}<0,05$ ), yakni nilai p-value Muscle Rectus Superior 0.026, berarti ada perbedaan terhadap variasi phase oversampling sedangkan secara objektif yaitu penilaiaan responden menunjukan bahwa terdapat perbedaan, dan dapat dilihat pada gambar 2.

\section{Muscle Rectus Inferior}

Dari hasil uji friedman pada tabel 4 menunjukan bahwa ( $\mathrm{p}>0,05$ ), yakni nilai $p$-value Muscle Rectus Inferior 0.326, berarti tidak ada perbedaan terhadap variasi phase oversampling sedangkan secara objektif yaitu penilaiaan responden juga menunjukan bahwa tidak terdapat perbedaan, dan dapat dilihat pada gambar 2.

\section{Optic Nerve}

Dari hasil uji friedman pada tabel 4 menunjukan bahwa ( $\mathrm{p}<0,05$ ), yakni nilai p-value Optic Nerve 0.023 , berarti ada perbedaan terhadap variasi phase oversampling sedangkan secara objektif yaitu penilaiaan responden menunjukan bahwa terdapat perbedaan, dan dapat dilihat pada gambar 2 .

\section{Hasil Uji Friedman Informasi Anatomi pada Keseluruhan Anatomi}

Pengujian untuk mengetahui perbedaan informasi citra anatomi secara keseluruhan anatomi terhadap variasi phase oversampling mendapatkan hasil sebagai berikut :

Tabel 5. Hasil Uji Friedman Informasi anatomi keseluruhan variasi phase oversampling

\begin{tabular}{ccc}
\hline Variasi & $p$-value & Keterangan \\
\hline Phase & & Ada perbedaan informasi \\
$\begin{array}{c}\text { Oversampling } \\
(13 \%, 52 \% \&\end{array}$ & 0,010 & $\begin{array}{c}\text { citra anatomi variasi } \\
\text { phase oversampling }\end{array}$ \\
$91 \%)$ & & . \\
\hline
\end{tabular}

Hasil uji Friedman didapatkan tingkat kepercayaan $95 \%$ $(\alpha=5 \%) p$-value lebih kecil dari $\alpha(\mathrm{p}<0,05)$, yakni sebesar 0,010. Maka Ho ditolak, bahwa ada perbedaan informasi anatomi secara keseluruhan irisan sagital oblique sekuen T1 SE Fat Saturation dengan Variasi Phase Oversampling pada Pemeriksaan MRI Orbita.

\section{Kualitas Citra}

Kualitas citra merupakan hasil dari scanning MRI Orbita dengan variasi Phase Oversampling.
Tabel 6. Hasil Akumulasi Nilai SNR dan CNR

\begin{tabular}{|r|l|l|r|r|r|r|}
\hline \multirow{2}{*}{ no } & \multicolumn{3}{|c|}{ SNR } & \multicolumn{3}{c|}{ CNR } \\
\cline { 2 - 7 } & $13 \%$ & $52 \%$ & $91 \%$ & $13 \%$ & $52 \%$ & $91 \%$ \\
\hline 1 & 207.83 & 237.33 & 263.26 & 79.75 & 176.88 & 156.74 \\
\hline 2 & 232.38 & 247.31 & 293.29 & 173.20 & 139.35 & 178.38 \\
\hline 3 & 197.58 & 360.68 & 373.94 & 123.52 & 236.59 & 243.36 \\
\hline 4 & 206.31 & 343.54 & 598.85 & 129.53 & 232.33 & 389.06 \\
\hline 5 & 231.98 & 366.26 & 445.79 & 163.76 & 188.49 & 228.90 \\
\hline 6 & 195.41 & 319.72 & 570.55 & 128.02 & 197.74 & 352.47 \\
\hline 7 & 205.40 & 311.70 & 380.83 & 118.67 & 125.54 & 222.17 \\
\hline 8 & 236.44 & 267.74 & 404.75 & 135.40 & 137.20 & 202.72 \\
\hline 9 & 163.52 & 284.03 & 280.94 & 138.30 & 190.65 & 187.97 \\
\hline 10 & 167.10 & 271.31 & 425.45 & 111.57 & 173.23 & 260.04 \\
\hline
\end{tabular}

Dari tabel 6. dapat dilihat hasil penilaian kualitas citra Signal to Noise Ratio dan Contrast to Noise Ratio. Data tersebut merupakan hasil akumulasi nilai SNR dan CNR area anatomi Vitreous, Lensa, Retro orbita, Muscle rectus superior, Muscle rectus inferior, Optic nerve dari seluruh variasi Phase Oversampling.

\section{Hasil Uji Friedman Keberadaan Artefak Aliasing}

Hasil dari penilaian setiap variasi phase oversampling terhadap adanya artefak aliasing dengan menggunakan skor 1 jika terdapat artefak dan mengganggu citra, skor 2 jika terdapat artefak tetapi tidak mengganggu citra, dan skor 3 jika tidak terdapat artefak pada citra. Berdasarkan hasil uji friedman didapatkan sebagai berikut :

Tabel 7. Hasil Uji Friedman keberadaan artefak aliasing pada variasi phase oversampling

\begin{tabular}{|c|c|c|}
\hline Variasi & $p$-value & Keterangan \\
\hline $\begin{array}{c}\text { Phase } \\
\text { Oversampling } \\
(13 \%, 52 \% \& 91 \%)\end{array}$ & 0,000 & $\begin{array}{c}\text { Ada perbedaan artefak } \\
\text { aliasing pada variasi } \\
\text { phase oversampling }\end{array}$ \\
\hline
\end{tabular}

Hasil uji Friedman didapatkan tingkat kepercayaan 95\% $(\alpha=5 \%) p$-value lebih kecil dari $\alpha(\mathrm{p}<0,05)$, yakni sebesar 0,010. Maka Ho ditolak, bahwa ada perbedaan informasi anatomi irisan sagital oblique sekuen T1 SE Fat Saturation dengan Variasi Phase Oversampling pada Pemerksaan MRI Orbita. Sedangkan pada gambar 2 terlihat terdapat berbedaan keberdaan artefak.

\section{Hasil Uji Friedman Kualitas Citra pada Keseluruhan Anatomi}

Berdasarkan data yang diperoleh sejumlah 30 citra maka semua data tidak berdistribusi normal, karena data kurang dari atau sama dengan 30. Sehinga pengujian selanjutnya menggunakan uji friedman.

Pengujian friedman dilakukan untuk mengetahui perbedaan kualitas citra (SNR dan CNR) potongan sagital oblique sekuen T1 SE Fat Saturation dengan variasi phase oversampling. 
Berikut pengujian untuk mengetahui perbedaan informasi citra anatomi secara keseluruhan terhadap variasi phase oversampling mendapatkan hasil sebagai berikut :

Tabel 8. Hasil Uji Friedman kualitas citra pada nilai SNR keseluruhan variasi phase oversampling

\begin{tabular}{ccc}
\hline Variasi & p-value & Keterangan \\
\hline $\begin{array}{c}\text { Phase Oversampling } \\
(13 \%, 52 \%, \& 91 \%)\end{array}$ & 0,000 & $\begin{array}{c}\text { Ada perbedaan } \\
\text { kualitas citra pada } \\
\text { nilai SNR variasi } \\
\text { phase oversampling }\end{array}$ \\
\hline
\end{tabular}

Hasil uji Friedman didapatkan tingkat kepercayaan 95\% $(\alpha=5 \%) p$-value lebih kecil dari $\alpha(\mathrm{p}<0,05)$, yakni sebesar 0,000. Maka Ho ditolak, bahwa ada perbedaan kualitas citra pada nilai SNR secara keseluruhan potongan sagital oblique sekuen T1 SE Fat Saturation dengan Variasi Phase Oversampling pada Pemeriksaan MRI Orbita. Secara objektif dapat dilihat pada gambar 2 bahwa ada perbedaan terhadap variasi phase oversampling.

Tabel 9. Hasil Uji Friedman kualitas citra pada nilai CNR keseluruhan variasi phase oversampling

\begin{tabular}{ccc}
\hline Variasi & p-value & Keterangan \\
\hline $\begin{array}{c}\text { Phase Oversampling } \\
(13 \%, 52 \%, \& 91 \%)\end{array}$ & 0,000 & $\begin{array}{c}\text { Ada perbedaan } \\
\text { kualitas citra pada } \\
\text { nilai CNR variasi } \\
\text { phase oversampling }\end{array}$ \\
\hline
\end{tabular}

Hasil uji Friedman didapatkan $p$-value lebih kecil dari $\alpha$ ( $\mathrm{p}<0,05$ ), yakni sebesar 0,000. Maka Ho ditolak, bahwa ada perbedaan kualitas citra pada nilai CNR secara keseluruhan potongan sagital oblique sekuen T1 SE Fat Saturation dengan Variasi Phase Oversampling pada Pemeriksaan MRI Orbita. Secara objektif dapat dilihat pada gambar 2 bahwa ada perbedaan terhadap variasi phase oversampling.

Hasil Mean Rank pada Informasi Anatomi dan Kualitas Citra

Hasil Mean Rank Informasi Anatomi pada Setiap Anatomi

Pada uji statistik Friedman terdapat nilai mean rank untuk mengetahui informasi anatomi yang lebih baik tiap anatomi antara variasi phase oversampling. Berdasarkan hasil uji tersebut didapatkan nilai mean rank sebagai berikut :

Tabel 10. Hasil mean rank uji Friedman informasi anatomi setiap anatomi pada variasi phase oversampling

\begin{tabular}{ccc}
\hline Kriteria Anatomi & Phase Oversampling & Rank \\
\hline \multirow{3}{*}{ Vitreous } & $13 \%$ & 1.65 \\
\cline { 2 - 3 } & $52 \%$ & 2.15 \\
\cline { 2 - 3 } Lensa & $91 \%$ & 2.20 \\
\cline { 2 - 3 } & $13 \%$ & 1.20 \\
\cline { 2 - 3 } & $52 \%$ & 2.30 \\
\hline \multirow{3}{*}{ Retro Orbita } & $91 \%$ & 2.50 \\
\cline { 2 - 3 } & $13 \%$ & 2.30 \\
\cline { 2 - 3 } & $52 \%$ & 1.85 \\
\hline Muscle Rectus & $91 \%$ & 1.85 \\
\hline
\end{tabular}

\begin{tabular}{ccc}
\hline \multirow{2}{*}{ Superior } & $52 \%$ & 1.90 \\
\cline { 2 - 3 } & $91 \%$ & 2.60 \\
\hline \multirow{2}{*}{$\begin{array}{c}\text { Muscle Rectus } \\
\text { Inferior }\end{array}$} & $13 \%$ & 1.80 \\
\cline { 2 - 3 } & $52 \%$ & 2.35 \\
\cline { 2 - 3 } & $91 \%$ & 1.85 \\
\cline { 2 - 3 } Optic Nerve & $13 \%$ & 1.40 \\
\cline { 2 - 3 } & $52 \%$ & 2.15 \\
\hline
\end{tabular}

Berdasarkan nilai mean rank didapatkan hasil informasi anatomi setiap anatomi, yang memiliki nilai mean rank terbesar pada anatomi Vitreous adalah variasi phase oversampling $91 \%$ sebesar 2.20 . Nilai mean rank terbesar anatomi Lensa adalah variasi phase oversampling 91\% sebesar 2.50. Nilai mean rank terbesar pada anatomi Retro Orbita adalah variasi phase oversampling 13\% sebesar 2.30 . Nilai mean rank terbesar pada anatomi Muscle Rectus Superior adalah variasi phase oversampling $91 \%$ sebesar 2.60 . Nilai mean rank terbesar anatomi Muscle Rectus Inferior adalah variasi phase oversampling $52 \%$ sebesar 2.35 . Nilai mean rank terbesar pada anatomi Optic Nerve adalah variasi phase oversampling $91 \%$ sebesar 2.45 (gambar 2).

Hal ini menyatakan bahwa phase oversampling $91 \%$ memiliki informasi anatomi lebih baik dibandingkan phase oversampling $13 \%$ dan $52 \%$.

\section{Hasil Mean Rank Informasi Anatomi pada Keseluruhan Anatomi}

Hasil dari setiap penilaian terhadap informasi anatomi dianalisis dengan melihat nilai mean rank untuk mengetahui informasi anatomi yang lebih baik antara variasi phase oversampling. Berdasarkan hasil uji tersebut didapatkan nilai mean rank sebagai berikut :

Tabel 11. Hasil mean rank uji friedman informasi anatomi keseluruhan anatomi

\begin{tabular}{cc}
\hline Phase Oversampling & Mean rank \\
\hline $13 \%$ & 1.73 \\
$52 \%$ & 2.06 \\
$91 \%$ & 2.22 \\
\hline
\end{tabular}

Berdasarkan tabel diatas nilai mean rank didapatkan hasil informasi anatomi secara keseluruhan antara variasi phase oversamplig $13 \%$ sebesar 1.73 , phase oversampling $52 \%$ sebesar 2.06, dan phase oversampling $91 \%$ sebesar 2.22 . Hal ini menyatakan bahwa phase oversampling $91 \%$ lebih baik dibandingkan phase oversampling $13 \%$ dan 52\% (gambar 2).

\section{Hasil Mean Rank Kualitas Citra pada Keseluruhan Anatomi}

Hasil dari setiap penilaian terhadap kualitas citra (nilai SNR dan nilai CNR) dianalisis dengan melihat nilai mean rank untuk mengetahui kualitas citra yang lebih baik antara variasi phase oversampling. Berdasarkan hasil uji tersebut didapatkan nilai mean rank sebagai berikut : 
Tabel 12. Hasil mean rank kualitas citra pada nilai SNR keseluruhan anatomi

\begin{tabular}{cc}
\hline Phase Oversampling & Mean rank \\
\hline $13 \%$ & 1.28 \\
$52 \%$ & 1.88 \\
$91 \%$ & 2.84 \\
\hline
\end{tabular}

Berdasarkan nilai mean rank didapatkan hasil kualitas citra pada nilai SNR secara keseluruhan anatomi antara variasi

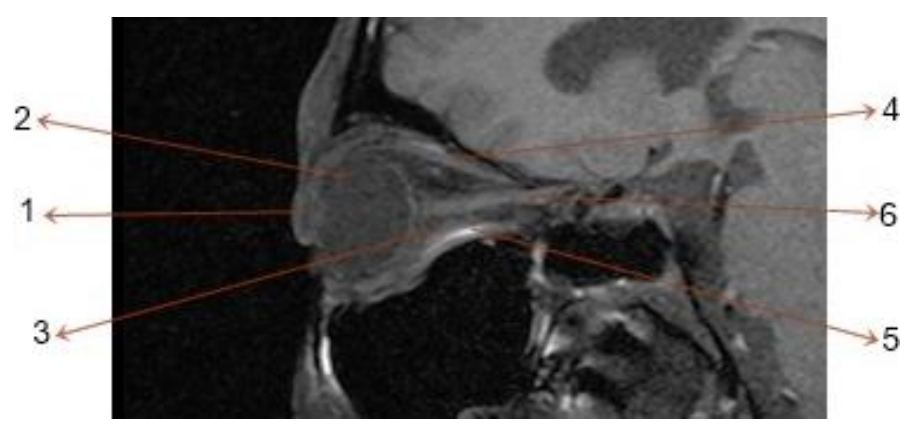

phase oversamplig $13 \%$ sebesar 1.28 , phase oversampling $52 \%$ sebesar 1.88 , dan phase oversampling $91 \%$ sebesar 2.84 . Hal ini menyatakan bahwa phase oversampling $91 \%$ memiliki kualitas citra (nilai SNR) lebih baik dibandingkan phase oversampling $13 \%$ dan $52 \%$ (gambar 2).

Tabel 13. Hasil mean rank uji friedman kualitas citra pada nilai CNR keseluruhan anatomi

\begin{tabular}{cc}
\hline Phase Oversampling & Mean rank \\
\hline $13 \%$ & 1.60 \\
$52 \%$ & 1.78 \\
$91 \%$ & 2.63 \\
\hline
\end{tabular}

Berdasarkan nilai mean rank didapatkan hasil kualitas citra pada nilai CNR secara keseluruhan anatomi antara variasi phase oversamplig $13 \%$ sebesar 1.60, phase oversampling $52 \%$ sebesar 1.78 , dan phase oversampling $91 \%$ sebesar 2.63. Hal ini menyatakan bahwa phase oversampling $91 \%$ memiliki kualitas citra (nilai CNR) lebih baik dibandingkan phase oversampling 13\% dan 52\% (gambar 2).

\section{DISKUSI}

Perbedaan Informasi Anatomi dan Kualitas Citra pada dengan Variasi Phase Oversampling

Berdasarkan hasil uji Friedman (tabel 4) pada penilaian kejelasan informasi anatomi dengan pengaturan variasi Phase Oversampling pada sekuen T1 SE Fat Saturation irisan sagital oblique, dihasilkan nilai $(p$-value $<0,05)$ berarti ada perbedaan informasi anatomi pada sekuen T1 SE Fat Saturation irisan sagital oblique dengan variasi phase oversampling pada pemeriksaan MRI Orbita.

Penilaian uji Friedman untuk mengetahui perbedaan informasi anatomi pada setiap anatomi diperoleh hasil Ho ditolak ( $p<0.05)$ yaitu bahwa ada perbedaan informasi anatomi pada beberapa kriteria anatomi, seperti Lensa, Muscle Rectus Superior, dan Optic Nerve. Sedangkan anatomi Retro Orbita, Veitreous, dan Muscle Rectus Inferior. Ho diterima ( $\mathrm{p}$ $>0,05)$ yakni tidak ada perbedaan informasi anatomi.

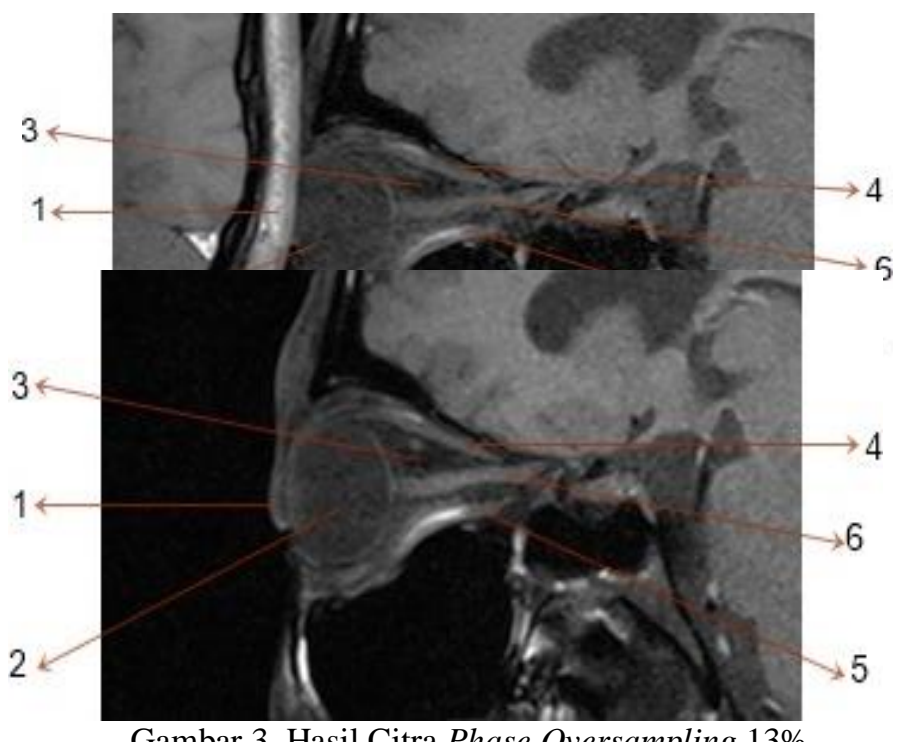

Gambar 3. Hasil Citra Phase Oversampling 13\% Gambar 4. Hasil Citra Phase Oversampling 52\%

Gambar 5. Hasil Citra Phase Oversampling 91\%.

Keterangan :

- Lensa

- Vitreous

- Retro Orbita

- Muscle Rectus Superior

- Muscle Rectus Inferior

- Optic Nerve

Anatomi optic nerve dihasilkan citra yang lebih jelas dan berbatas tegas pada phase oversampling 91\% (Gambar 5) dibandingkan citra pada phase oversampling 13\% (Gambar 3) dan 52\% (Gambar 4). Anatomi muscle rectus superior variasi phase oversampling 13\% (gambar 3) tidak terlalu jelas, sedangkan phase oversampling 52\% (gambar 4) dan $91 \%$ (gambar 5) memiliki gambaran yang jelas dan berbatas tegas.

Anatomi retro orbita dan vitreous tidak terdapat perbedaan informasi anatomi (tabel 4) karena kandungan dari retro orbita dan vitreous berupa lemak sehingga jika menggunakan teknik fat saturation maka lemak akan ditekan sehingga secara kasat mata dari penglihatan responden tidak ada perbedaan. Anatomi Muscle rectus inferior tidak terdapat perbedaan (tabel 4) karena terdapat inhomogenitas magnetik pada daerah tersebut yang menyebabkan gambaran lebih hiperintens (gambar 3-5) sehingga tidak dapat di nilai dengan baik oleh responden. Inhomogenitas magnetik terjadi karena organ orbita mengandung campuran komponen air dan lemak. 
Hal ini sesuai dengan pendapat Nayak (2012) bahwa banyaknya lemak dan air pada orbita menyebabkan inhomogenitas magnetik sehingga mengganggu spatial resolusi dan hilangnya detail anatomi, sehingga teknik fat saturation digunakan untuk memperbaiki visualisasi struktur anatomi lainnya.

Inhomogenitas magnetik terjadi karena pada sekuen T1 SE Fat Saturation tidak dilakukan teknik shimming sebelum scanning dimulai. Shimming berfungsi untuk menghasilkan magnet yang homogen dengan cara memisahkan antara sinyal air dan sinyal lemak, sehingga akan dihasilkan teknik fat saturation yang baik. (Cameron, 2012).

\section{Perbedaan Kualitas Citra (SNR dan CNR)}

Hasil uji statistik Friedman (tabel 8) pada setiap kriteria anatomi untuk mengetahui perbedaan kualitas citra pada nilai SNR diperoleh dengan Ho ditolak ( $\mathrm{p}<0.05)$, bahwa ada perbedaan kualitas citra nilai SNR pada anatomi, seperti Vitreous, Lensa, Retro orbita, Muscle rectus superior, Muscle rectus inferior, dan Optic nerve.

Hasil akumulasi nilai SNR (tabel 6) pada keseluruhan anatomi menghasilkan semakin besar phase oversampling maka kualitas citra (nilai SNR) akan semakin meningkat. Sedangkan pada hasil citra (gambar 3-5) dapat dilihat memiliki kualitas yang meningkat.

Hasil akumulasi nilai CNR (tabel 6) pada keseluruhan anatomi menghasilkan semakin besar phase oversampling maka kualitas citra (nilai CNR) akan semakin meningkat.

Penilaian uji statistik Friedman pada keseluruhan anatomi untuk mengetahui perbedaan kualitas citra pada nilai CNR diperoleh dengan Ho ditolak ( $\mathrm{p}<0.05$ ), bahwa ada perbedaan kualitas citra nilai CNR pada anatomi (tabel 9).

Menurut penulis dari hasil uji friedman didapatkan bahwa terdapat perbedaan informasi citra, dan kualitas citra (CNR dan SNR) terhadap variasi phase oversampling, ini disebabkan pemeriksaan MRI Orbita menggunakan teknik Fat saturation juga mempengaruhi adanya perbedaan karena orbita banyak mengandung komponen lemak yang dapat menghasilkan sinyal hiperintens, sehingga teknik fat saturation akan menekan lemak untuk menghasilkan spatial resolution dan detail anatomi yang lebih baik pada citra. Hal ini sesuai dengan pendapat Nayak (2012) bahwa banyaknya komponen lemak dan air pada orbita menyebabkan inhomogenitas magnetik sehingga mengganggu spatial resolusi dan hilangnya detail anatomi, sehingga teknik fat saturation digunakan untuk memperbaiki visualisasi struktur anatomi lainnya.

Penilaian dengan uji statistik Friedman pada penilaian kederadaan artefak aliasing (tabel 7) menunjukan bahwa ada perbedaan artefak aliasing pada sekuen T1 SE Fat Saturation irisan sagital oblique dengan variasi phase oversampling pada pemeriksaan MRI Orbita. Artefak aliasing terlihat pada anatomi lensa variasi phase oversampling 13\% (gambar 3) sedangkan pada phase oversampling 52\% (gambar 4) dan $91 \%$ (gambar 5) tidak terdapat artefak aliasing.

Artefak aliasing terjadi karena pemeriksaan MRI orbita dilakukan dengan menggunakan head coil sedangkan organ yang akan diperiksa adalah salah satu orbita. Penggunaan head coil menyebabkan seluruh kepala masuk kedalam area akuisisi, sedangkan area yang akan diperiksa hanya orbita yang dibatasi FOV, sehingga menyebabkan terbentuknya artefak aliasing. Hal ini sesuai dengan pendapat menurut Westbrook (2011) bahwa artefak aliasing terjadi ketika area FOV lebih kecil dari keseluruhan objek yang dicitrakan (tercakup dalam coil). Bagian anatomi tersebut tampak seperti bertumpuk dalam satu gambar. Bisa terjadi dalam frekuensi encoding maupun phase encoding.

Metode untuk menghilangkan artefak aliasing pada pemeriksaan MRI Orbita adalah menggunakan phase oversampling. Phase oversampling akan melipatgandakan ukuran matriks Number Phase Encode (NPE) dan juga meningkatkan jumlah langkah phase encoding menjadi dua kali lipat nilai FOV pada area orbita, sehingga anatomi orbita di dalam FOV mendapatkan phase encode yang benar, dan anatomi di luar FOV area orbita dihilangkan dan menghasilkan citra yang bersih dari artefak aliasing.

Hal ini sesuai dengan pendapat McRobbie (2006) bahwa phase oversampling untuk meningkatkan ukuran matriks Number Phase Encode (NPE) dan juga meningkatkan jumlah langkah phase encoding menjadi dua kali lipat nilai FOV yang di dapatkan, sehingga anatomi di dalam FOV yang diinginkan mendapatkan phase encode yang benar, dan anatomi di luar FOV yang tidak diinginkan dihilangkan dan menghasilkan citra yang bersih dari artefak aliasing. Peningkatan langkah phase encode akan meningkatkan SNR.

Perbedaan kualitas citra (SNR dan CNR) disebabkan karena semakin besar phase oversampling yang digunakan maka ukuran matriks number phase encode meningkat, sehingga encoding pada setiap pixel pada anatomi tersebut meningkat, maka menyebabkan (kualitas citra) nilai SNR dan nilai CNR meningkat.

\section{Nilai Phase Oversampling yang dapat Menghasilkan Informasi Citra Optimal.}

Hasil nilai mean rank informasi anatomi (tabel 11) pada anatomi orbita penggunaan Phase oversampling 91\% dapat menampakkan hasil citra Orbita secara keseluruhan paling optimal. Namun, hasil mean rank informasi anatomi antara phase oversampling 52\% (gambar 4) dengan phase oversampling 91\% (gambar 5) tidak terlampau jauh. Hal ini menunjukkan bahwa perbedaan pada citra antara kedua phase oversampling tersebut tidak terlalu besar.

\section{Nilai Phase Oversampling yang dapat Menghasilkan} Kualitas Citra (SNR dan CNR) Optimal.

Nilai mean rank pada keseluruh organ orbita pada kualitas citra nilai SNR (tabel 12) dengan hasil mean rank tersebut dapat diketahui bahwa pada penggunaan Phase oversampling $91 \%$ dapat menampakkan hasil citra Orbita secara keseluruhan paling optimal.

Hasil mean rank pada keseluruh organ orbita pada kualitas citra nilai CNR (tabel 13) variasi Phase oversampling 91\% (gambar 5) dapat menampakkan hasil citra Orbita paling optimal.

Nilai mean rank hasil uji friedman kualitas citra (nilai SNR dan nilai CNR) antara phase oversampling 52\% (gambar 4) dengan phase oversampling $91 \%$ terlampau jauh. Hal ini 
menunjukkan bahwa perbedaan yang signifikan pada citra antara kedua phase oversampling besar.

Menurut penulis berdasarkan dari hasil mean rank variasi phase oversampling pada sekuens T1 SE Fat Saturation irisan sagital oblique menunjukan kenaikan nilai, dimana ketika phase oversampling semakin besar maka informasi anatomi semakin baik, artefak semakin hilang, dan kualitas citra (nilai SNR dan nilai CNR) semakin meningkat. Hal ini disebabkan oleh, nilai phase oversampling yang semakin tinggi maka ukuran matriks Number of Phase Encode (NPE) akan meningkat sehingga encoding pada setiap pixel akan meningkat, dan dalam satu kali akuisisi pengisian citra dalam $k$-space disampling berulang sehingga citra yang dihasilkan dapat meminimalisir munculnya artefak aliasing dan meningkatkan SNR.

Hal ini juga sesuai dengan pendapat Joachim (2009) bahwa teknik phase oversampling akan meningkatkan FOV pada Phase encode direction dan juga meningkatkan jumlah tahapan phase encode sehingga ukuran pixel tetap sama. phase encode yang meningkat akan meningkatkan SNR, dan menghilangkan artefak aliasing.

Menurut penulis nilai terbaik pada variasi phase oversampling adalah 91\% (gambar 5) karena dapat menghasilkan kualitas citra yang baik antara jaringan pada orbita sehingga dapat membantu dokter radiologi dalam mengevaluasi hasil citra MRI.

\section{Simpulan}

Hasil penelitian menunjukan ada perbedaan yang signifikan pada anatomi lensa terdapat artefak aliasing variasi phase oversampling $13 \%$, sedangkan phase oversampling $52 \%$ dan $91 \%$ tidak terdapat artefak aliasing. Anatomi optic nerve memiliki citra yang jelas dan berbatas tegas pada phase oversampling $91 \%$ dibandingkan phase oversampling $13 \%$ dan $52 \%$. Ada perbedaan informasi anatomi pada sekuen T1 SE Fat Saturation irisan sagital oblique dengan variasi phase oversampling. Anatomi Lensa, Muscle rectus superior, dan Optic nerve. Signifikan dengan p-value kurang dari 0.05 ( $p$ value < 0.05). Anatomi Retro orbita, Muscle rectus inferior, dan Vitreous tidak terdapat perbedaan informasi anatomi pada sekuen T1 SE Fat Saturation irisan sagital oblique dengan variasi phase oversampling. Hasil penelitian kualias citra (nilai SNR dan CNR) menunjukan bahwa nilai SNR dan CNR pada phase oversampling $91 \%$ lebih besar dibanding phase oversampling 13\%, sedangkan pada uji friedman (SNR dan CNR) menunjukan nilai 0.000 ( $p$-value $<0.05$ ) yang berarti Ada perbedaan kualitas citra pada sekuen T1 SE Fat Saturation irisan sagital oblique dengan variasi phase oversampling.

Berdasarkan hasil mean rank dapat disimpulkan bahwa nilai phase oversampling $91 \%$ yang paling optimal untuk menghasilkan informasi anatomi dan kualitas citra yang baik pada pemeriksaan MRI Orbita.

\section{Daftar Pustaka}

Cameron, Ian. 2012. Techniques of Fat Suppression. Ottawa : Canada

Elmaoglu, Muhammed. 2012. MRI Handbook MR Physics, Patient Positioning, and Protocols. Department of Medical Imaging Technologies : Turkey

Erasmus, L, J., Hurter, D., Naudé, M., Kritzinger, H, G. Acho, S,. 2004. A short overview of MRI artefacts. Department of Diagnostic Radiology University of the Free State Bloemfontein : Bloemfontein

Hashemi, Ray Hasman., William G Bradley and Cristopher J Lisanti, 2010. MRI the Basic, Third Edition. Wolters Kluwer Health : USA

Ilyas, Sidarta. 2015. Ilmu Penyakit Mata (Edisi 5). Balai Penerbit FKUI : Jakarta

Joachim, Graessner. 2009. The Signal-to-Noise Indicator or How to Navigate the 'Bermuda Triangle'. www.static.healthcare.siemens.http.

McRobbie, Donald W., Elizabeth A Moore., Martin J Graves., Martin R Prince. 2006. MRI From Picture to Proton second edition. Cambridge : London

Moeller, Reif. 2007. Pocket Atlas of Sectional Anatomy Computer Tomography and Magnetic Resonance Imaging. Appl, Wemding : Munich

Nayak, Barun Kumar., Savari Desai., dan Shailendra Maheshwari. 2013. Interpretation of magnetic resonance imaging of orbit: Simplified for ophthalmologists (Part I). Department of Ophthalmology, P. D. Hinduja Hospital and Medical Research Center : Mumbai, India

Paulsen, Friedrich., Waschke, Jens. 2011. Sobotta Atlas of Human Anatomy Head, Neck and Neuroanatomy. Elsevier : Munich

Rasad, Sjahriar. 2005. Radiologi Diagnostik. Cetakan ketujuh. Balai Penerbit FKUI: Jakarta

Sugiyono. 2012. Metode Penelitian Pendidikan Pendekatan Kuantitatif, Kualitatif, Dan R\&B. Alfabeta : Bandung

Sopiyudin, M Dahlan. 2011. Statistik Untuk Kedokteran dan Kesehatan. Salemba Medika: Jakarta.

Westbrook, Catherine., Carolyn Kaut Roth., John Talbot. 2011. MRI in Practice, Fourth Edition. Blackwell : UK

Westbrook, Catherine. 2014. Handbook Of MRI Technique, Fourth Edition. Blackwell Science: Oxford 